\title{
Sustainability of Bosnia and Herzegovina's international trade flows
}

\section{Održivost međunarodnih trgovinskih tokova Bosne i Hercegovine}

\begin{abstract}
The aim of this research is to examine the sustainability of international trade flows of Bosnia and Herzegovina with the rest of the world. The data sample consists of quarterly data from the first quarter of 2008 to the last quarter of 2016. Johansen tests of cointegration indicated that exports and imports are cointegrated in case of Bosnia and Herzegovina and Vector Error Correction Model (VECM) is estimated and tested. Research results revealed bidirectional weakly sustainable relationship between exports and imports pointing out the need to improve external competitiveness of Bosnia and Herzegovina's economy.
\end{abstract}

Keywords: Import, Export, Sustainability, Bosnia and Herzegovina

JEL classification: C01, C05, C34, F1, F3

\section{Sažetak}

Cilj ovog istraživanja je istražiti održivost međunarodnih trgovinskih tokova Bosne i Hercegovine s ostatkom svijeta. Uzorak se sastoji od kvartalnih podataka od prvog kvartala 2008. do posljednjeg kvartala 2016. Testovi kointegracije potvrdili su dugoročnu ravnotežu te postojanje zajedničkog stohastičkog trenda između izvoza i uvoza Bosne i Hercegovine. Procijenjeni model korekcije pogrešaka (VECM) ukazuje na postojanje obostranih međusobnih utjecaja između uvoza i izvoza. Rezultati istraživanja pokazali su slabu održivost međunarodnih trgovinskih tokova te posljedično potrebu unaprijeđenja vanjske konkurentnosti bosansko-hercegovačkog gospodarstva.

Ključne riječi: vektorski model korekcije pogrešaka, uvoz, izvoz, Bosna i Hercegovina JEL klasifikacija: C01, C05, C34, F1, F3

\section{Introduction}

The literature dedicated to examining the relationship between exports and imports is extensive. However, while some research supports the existence of a cointegrating relationship, the other pointed out weak or no cointegration. Therefore, the literature is inconclusive with respect to the cointegration relationship between exports and imports. Bosnia and Herzegovina belongs to the group of European post-transition countries while being specific in regards to its political and economic position. Sustainability of Bosnia and Herzegovina's international trade flows has not been considered in the literature and this paper aims to make a step ahead towards explaining the relationship between exports and imports of Bosnia and Herzegovina. This paper follows the inter-temporal approach to sustainability of international trade flows (Husted, 1992) and the case of Bosnia and Herzegovina.

The rest of this paper is organized as follows: Section 2 briefly summarizes the theoretical
Assoc. prof. Branimir Skoko, PhD

Faculty of Economics, University of Mostar E-mail: branimir.skoko@ef.sum.ba

\section{Pero Zovko}

Faculty of Economics, University of Mosta E-mail:zovkop@gmail.com

\section{Doc. dr.sc. Branimir Skoko}

Ekonomski fakultet Sveučilišta u Mostaru E-mail: branimir.skoko@ef.sum.ba

\section{Pero Zovko}

Ekonomski fakultet Sveučilišta u Mostaru E-mail:zovkop@gmail.com 
Skoko, B., Zovko, P.

Sustainability of Bosnia and Herzegovina's international trade flows foundation and existing literature related to the topic under consideration. Section 3 presents the research data and methodology, while Section 4 provides research results and discussion and final section provides an overview of the main findings of the research.

\section{Literature overview}

This paper uses literature based on Husted (1992) who laid down the theoretical foundation for inter-temporal approach to sustainability of international trade flows. Along with methodological development, empirical literature brings various empirical evidence from all over the globe. Plat (2011) followed the autoregressive distributed lag approach for the period of January 2000 to June 2010 and examined the case of Turkey. The results indicated the weak sustainability of the Turkish international trade flows. Brissimis et al. (2012) based on the intertemporal approach and cointegration analysis examined Greece's external sustainability over the period from 1960 to 2007 and found weakly sustainable relationship between exports and imports. Chen (2011) examined the sustainability of international trade flows for Australia, the Czech Republic, Finland, Hungary, New Zealand, Portugal and Spain. The results revealed unsustainable trade flows of the observed countries. Holmeset et al. (2011) examined the sustainability of India's current account using data from 1950 onwards and found the regime of non-cointegration until the late 1990s and the regime of cointegration after that. Gnimassoun and Coulibaly (2014) examined current account sustainability in Sub-Saharan Africa and found that current accounts have been globally sustainable in Sub-Saharan Africa countries over the 1980-2011 period. Greenidge et al. (2011) examined the current account of Barbados over the period from 1960 to 2006 and found that the current account is sustainable while deviations from long-run equilibrium between real exports and imports are corrected in the short-run with imports making the adjustment. Following the cointegration stability test, Hye and Siddiqui (2010) found that imports cause the exports from the period of 2003 and exports cause the imports from 1994 to 2004. Insel and Kayikci (2012) evaluated the current account deficit of Turkey and found that Turkey would continue to have current account deficits in the next years and sustainability of these deficits has become increasingly difficult. Kalyoncu and Ozturk (2010) found a unique long run or equilibrium relationship among real exports and imports in the case of Peru, while in the case of Colombia, Venezuela, Mexico, Brazil and Argentina, cointegration results indicated that these countries' current accounts are not sustainable in the long run. Cunado et al. (2010) reported little or no evidence of current account sustainability in the European countries. Shastri et al. (2018) found strong sustainability in case of India, Bangladesh and Nepal, whereas weak sustainability was found for Sri Lanka and Pakistan pointing out the need for policy interventions. Camarero et al. (2013) analysed the external sustainability group of 23 OECD countries and results suggested strong sustainability for six countries. Destaingset et al. (2013) found that current account deficit of Kenya may not be sustainable in the long-run. Dumitriu et al.(2009) examined the cointegration and causality between Romanian exports and imports and found that current account deficits are not sustainable. The international trade sustainability has been examined for the neighbouring countries of Bosnia and Herzegovina as well. Following VECM, Franc and Peulić (2017) found cointegrated relationship between exports and imports in case of Slovenia while the import to export pattern was detected as the one that dominated. Bošnjak et al. (2018) followed panel cointegration approach and found the weakly sustainable pattern of international trade between Croatia and other EU member countries. Following the presented literature, there is no common conclusion regarding the relationship between exports and imports. This paper contributes to the debate while presenting the case of Bosnia and Herzegovina.

\section{Empirical data and methodology}

The research is based on the quarterly data sample on imports and export of goods and services from the first quarter of 2008 up to the last quarter of 2016 retrieved from the Statistical bureau of Bosnia and Herzegovina. Descriptive statistics for the observed series is provided in Table 1 while development of the considered series is illustrated in Figure 1 in the Appendix. 
Table 1 Descriptive statistic for the observed variables

\begin{tabular}{|c|c|c|}
\hline & $\log (\operatorname{lmp})$ & $\log (\operatorname{Exp})$ \\
\hline Min. & 14.81 & 14.15 \\
\hline 1st Qu. & 15.00 & 14.41 \\
\hline Median & 15.04 & 14.49 \\
\hline Mean & 15.04 & 14.49 \\
\hline 3rd Qu. & 15.10 & 14.59 \\
\hline Max. & 15.22 & 14.79 \\
\hline
\end{tabular}

Source: the authors.

The descriptive statistics in Table 1 illustrates the lower values for exports series compared to imports. The development of the net exports series is provided in Figure 1 in the Appendix. As illustrated in Figure 1, Bosnia and Herzegovina experienced the persistent deficit in international trade over the considered time span. Based on standard unit root tests (ADF, PP, KPSS) the stationarity diagnostic for exports and imports series were provided. Following the results from unit root tests, Johansen (1995) cointegration test was performed. Based on the cointegration tests results, Johansen (1988, 1991) and Johansen and Juselius (1990) Vector Error Correction Model (VECM) were employed and estimates were provided. Using variance decomposition and impulse response function the dynamic properties of the estimated system are presented. The forecast errors of variables were divided into the proportions attributable to shocks in every single variable in the system. Therefore, that can be considered as an out-of-sample causality test (Kling and Bessler, 1985). Following Sims (1982), in case the variable is fully forecasted from its own lagged values, all of its forecast error variances will be explained by its own shocks. Impulse response function illustrates the effects of shocks on the adjustment pattern of the variables.

\section{Research results and discussions}

Using the data and methodological procedure presented in the section Empirical data and methodology, the unit root tests are summarized in Table 2.

Following the results in Table 2, the imports and exports series are integrated of the first order and therefore we proceeded with tests of cointegration.

Table 2 Unit root test results

\begin{tabular}{|c|c|c|c|c|}
\hline \multirow{2}{*}{ Variable and test } & \multicolumn{2}{|c|}{ Levels } & \multicolumn{2}{|c|}{ First difference } \\
\hline & Constant & Constant and trend & Constant & Constant and trend \\
\hline ADF test & \multicolumn{4}{|c|}{ t-stat. } \\
\hline $\log (\operatorname{lmp})$ & 1.149897 & -1.782263 & -10.16681 & -4.706041 \\
\hline $\log (\operatorname{Exp})$ & 0.661129 & -3.295445 & -7.436043 & -7.537028 \\
\hline PP test & \multicolumn{4}{|c|}{ Adj.t-stat. } \\
\hline $\log (\operatorname{lmp})$ & -4.017480 & -4.744686 & -9.523450 & -11.35970 \\
\hline $\log ($ Exp) & -2.210148 & -6.061912 & -9.438618 & -9.621427 \\
\hline KPSS test & \multicolumn{4}{|c|}{ LM-stat. } \\
\hline $\log (\operatorname{Imp})$ & 0.584735 & 0.153484 & 0.190775 & 0.147518 \\
\hline $\log (\operatorname{Exp})$ & 0.796271 & 0.194077 & 0.158002 & 0.154944 \\
\hline
\end{tabular}

Source: the authors.

Table 3 The contegration test results

\begin{tabular}{|c|c|c|c|}
\hline Hypothesized No. of CE(s) & Eigenvalue & Trace Statistic & 0.05 Critical Value \\
\hline None & 0.410753 & 20.86925 & 15.49471 \\
\hline At most 1 & 0.081388 & 2.886312 & 3.841466 \\
\hline \multicolumn{4}{|c|}{ Max-Eigen statistics } \\
\hline None & 0.410753 & 17.98293 & 14.26460 \\
\hline At most 1 & 0.081388 & 2.886312 & 3.841466 \\
\hline
\end{tabular}

Source: the authors.

Skoko, B., Zovko, P.

Sustainability of Bosnia and Herzegovina's international trade flows 
Skoko, B., Zovko, P.

Sustainability of Bosnia and Herzegovina's international trade flows

Table 4 The model estimates and diagnostic tests

\begin{tabular}{|c|c|c|}
\hline Variables & $\Delta \log (\operatorname{Imp})_{i}$ & $\Delta \log (\operatorname{Exp})$ \\
\hline Intercept & $\begin{array}{l}-0.0032 \\
(0.0102)\end{array}$ & $\begin{array}{c}0.0199 \\
(0.0120)\end{array}$ \\
\hline$w_{t-1}$ & $\begin{array}{c}-0.5107 \\
(0.1027)^{* * * *}\end{array}$ & $\begin{array}{l}-0.2243 \\
(0.1215)^{*}\end{array}$ \\
\hline$\Delta \log (\operatorname{Imp})_{t-1}$ & $\begin{array}{c}-0.4947 \\
(0.1860)^{* *}\end{array}$ & $\begin{array}{l}-0.1296 \\
(0.2200)\end{array}$ \\
\hline$\Delta \log (\operatorname{Imp})_{t-2}$ & $\begin{array}{c}-0.5234 \\
(0.2115)^{* *}\end{array}$ & $\begin{array}{c}-0.5408 \\
(0.2503)^{* *}\end{array}$ \\
\hline$\Delta \log (\operatorname{Imp})_{t-3}$ & $\begin{array}{c}-0.6594 \\
(0.1855)^{* * * *}\end{array}$ & $\begin{array}{c}-0.4463 \\
(0.2194)^{*}\end{array}$ \\
\hline$\Delta \log (\operatorname{Exp})_{t-1}$ & $\begin{array}{l}-0.1430 \\
(0.2306)\end{array}$ & $\begin{array}{c}-0.5657 \\
(0.2729)^{*}\end{array}$ \\
\hline$\Delta \log (\operatorname{Exp})_{t-2}$ & $\begin{array}{c}-0.3960 \\
(0.2176)^{*}\end{array}$ & $\begin{array}{c}-0.4877 \\
(0.2574)^{*}\end{array}$ \\
\hline$\Delta \log (\operatorname{Exp})_{t-3}$ & $\begin{array}{c}0.0099 \\
(0.2124)\end{array}$ & $\begin{array}{l}-0.0324 \\
(0.2513)\end{array}$ \\
\hline \multicolumn{3}{|c|}{ Cointegrating vector: $(1,-1.037892)$} \\
\hline AIC: -343.153 & \multirow{2}{*}{$\begin{array}{c}\text { BIC: }-319.909 \\
\text { Diagnostics tests }\end{array}$} & SSR: 0.1044588 \\
\hline & & \\
\hline$\Delta \log (\operatorname{Imp})_{t}$ & Diagnostics tests & $\Delta \log (\operatorname{Exp})_{t}$ \\
\hline \multicolumn{2}{|c|}{ Arch test: 2.5325 p-value: 0.4694} & Arch test: 2.5399 p-value: 0.4681 \\
\hline \multicolumn{2}{|c|}{ Ljung-Box test: 4.9568 p-value: 0.175} & Ljung-Box test: 0.2568 p-value: 0.9679 \\
\hline \multicolumn{2}{|c|}{ Jarque-Berra test: 0.54931 p-value: 0.7598} & Jarque-Berra test: 1.3711 p-value: 0.5038 \\
\hline
\end{tabular}

Source: the authors.

Notes: Estimations are performed using the Maximum Likelihood (ML) estimator; standard errors are in brackets; ******, denote significance at the: $1 \%$ and $5 \%$ significance level, respectively.

The results of tests for cointegration are presented in Table 3.

Following the test results in Table 3, the null hypothesis of no cointegration between the observed series was easily rejected. Therefore, the observed series share a common stochastic trend and VECM models were specified and tested. The VECM model for sustainability of Bosnia and Herzegovina's international trade is given in Table 4.

The lag selection of the estimated VECM model in Table 4 was following Akaike's information criterion (AIC). The results in Table 4 supports the existence of the long-run equilibrium between exports and imports of Bosnia and Herzegovina and indicate sizeable adjustments towards long run equilibrium governed by imports. Even though the adjustments were governed by exports as well. Forecast error variance decomposition in Figure 4 in the Appendix as well as an impulse response function in Figure 2 and Figure 3 in the Appendix illustrates the interrelationship between the observed series. Following the ARCH test, the variance of residuals is homoscedastic. Ljung-Box test indicate no autocorrelations while Jarque-Berra test indicated that the residuals of the estimated model are normally distributed. Therefore, the diagnostics test indicated no misspecification of the estimated model. Following the research results in this paper, the international trade of Bosnia and Herzegovina is weakly sustainable. Furthermore, the deficit in international trade has persisted. Consequently, the research results point out the source of financing deficit in international trade of Bosnia and Herzegovina. However, this question remains for further research and suggestion is to examine the role of remittances.

\section{Conclusion}

There are several conclusions that can be drawn from research presented in this paper. Firstly, the literature reviewed in this paper points out various relationships between exports and imports indicating different and country specific conclusions regarding the sustainability of international trade. Following research results in this paper, international trade of Bosnia and Herzegovina 
can be considered as weakly sustainable with the existence of a long run equilibrium relationship. Furthermore, Bosnia and Herzegovina has experienced the persistent deficit in international trade. When disequilibrium occurred, the adjustment towards long run relationship was mostly governed by imports and adjusted within six months. When governed by exports the adjustment would last for more than a year. The research results clearly indicate the need for structural reforms of the economy of Bosnia and Herzegovina to increase the competitiveness and obtain the external sustainability. The recommendation for further research is to take into account the role of remittances since the deficit in international trade of Bosnia and Herzegovina might be financed through remittances from abroad.

\section{Appendix}

Figure 1 Net exports series in (natural) log values of Bosnia and Herzegovina

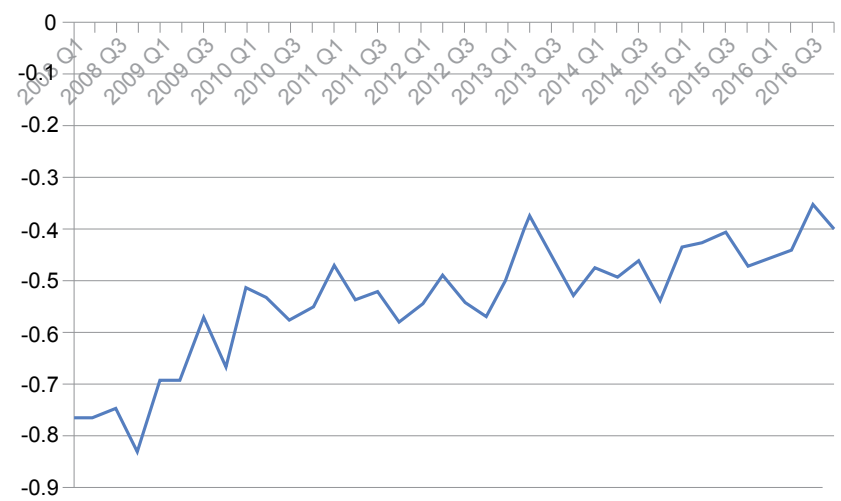

Source: the authors. 


\section{Skoko, B., Zovko, P.}

Sustainability of Bosnia and Herzegovina's international trade flows
Figure 2 Impulse response function from exports

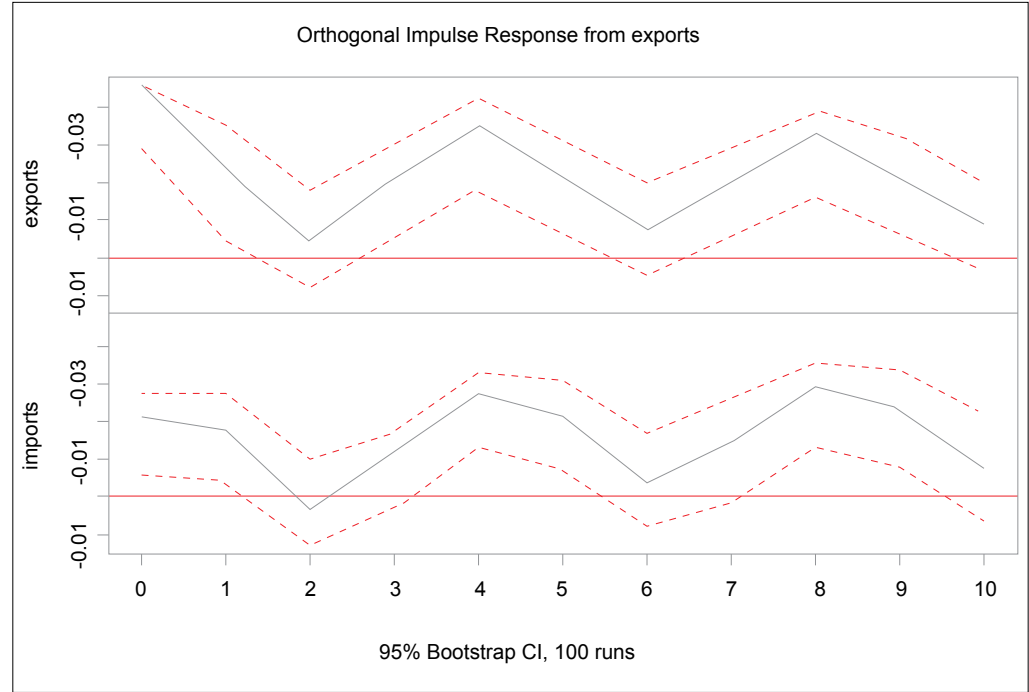

Source: the authors.

Figure 3 Impulse response function from imports

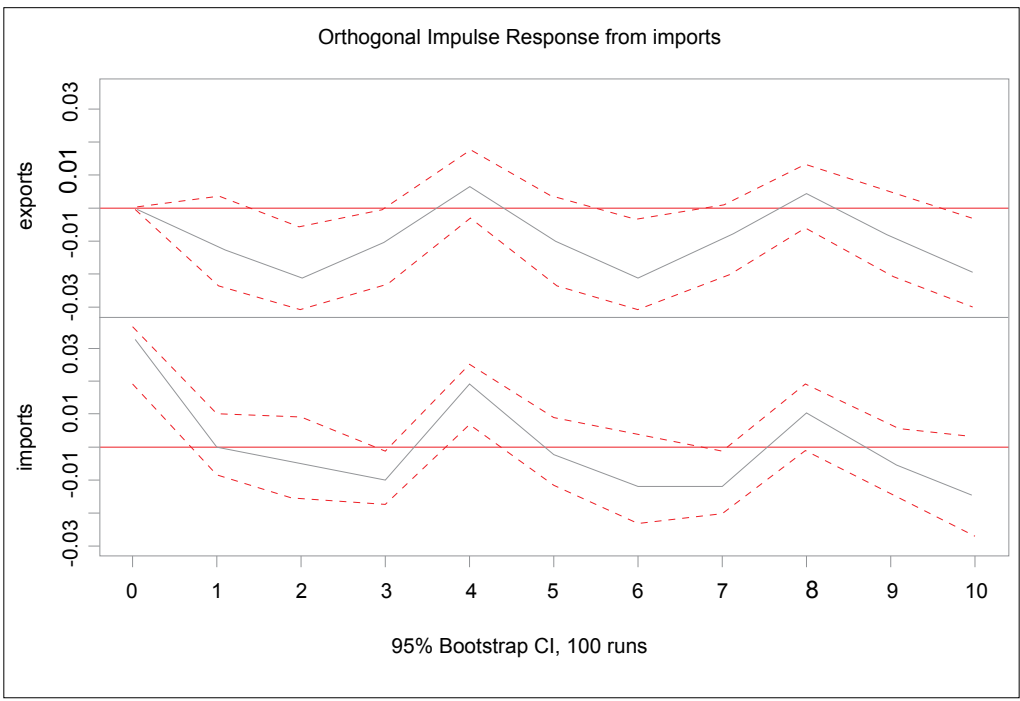

Source: the authors. 
Figure 4 Forecast error variance decomposition

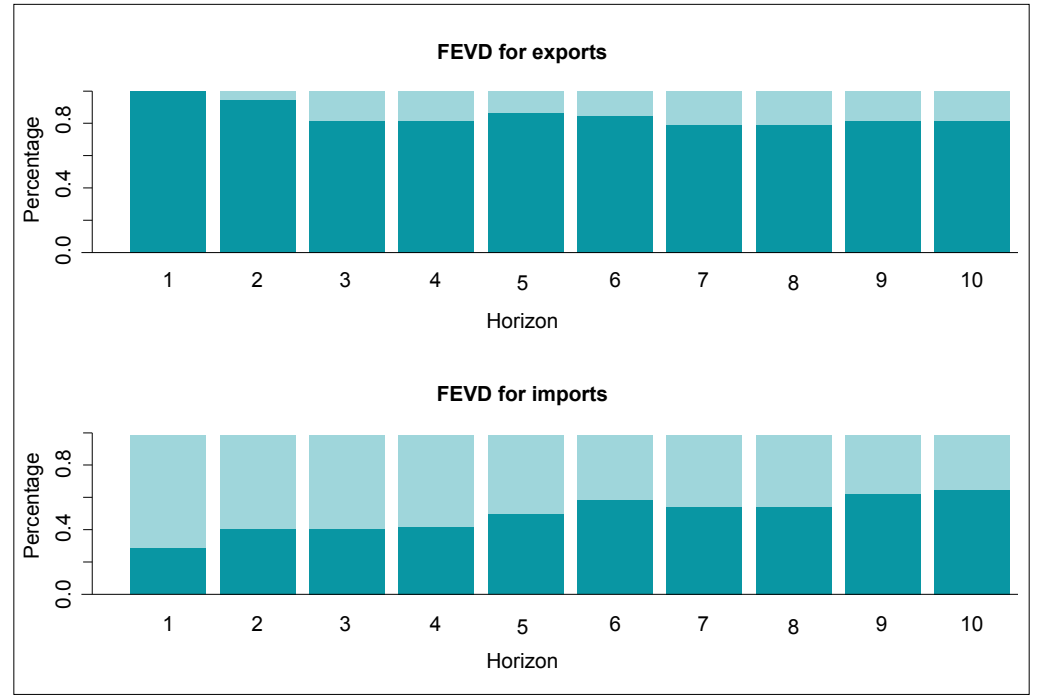

Source: the authors.

\section{Literature}

Bošnjak, M., Bilas, V., Novak, I. (2018) Sustainability of merchandise trade flows between Croatia and other EU member status - panel cointegration approach. Panoeconomicus, Advanced inline publication.

Brissimis, S. N., Hondroyiannis, G., Papazoglou, C., Tsaveas, N. T., Vasardani, M.A. (2012) Current account determinants and external sustainability in periods of structural change. Economic Change and Restructuring, 45 (1-2): 71-95.

Camarero,M., Carrion-i-Silvestre,J. L., Tamarit,C.(2013) Global imbalances and the intertemporal external budget constraint: A multicointegration approach. Journal of Banking \& Finance, 37 (12): 5357-5372.

Chen, S. W. (2011) Current account deficits and sustainability: Evidence from the OECD countries. Economic Modelling, 28 (4): 1455-1464.

Cunado, J., Gil-Alana, L. A., De Gracia, F. P. (2010) European current account sustainability: New evidence based on unit roots and fractional integration. Eastern Economic Journal, 36 (2): 177-187.

Destaings, N. N., Mohamed, M. S., Gideon, M. (2013) Is Kenya's current account sustainable? A stationarity and cointegration approach. European Scientific Journal, 9 (25): 171-190.

Dumitriu, R., Stefanescu, R., Nistor, C. (2009) Cointegration and causality between Romanian exports and imports. Published in: Proceedings of the 4th International Conference on Business Excellence ICBE, 16-17 October, 2009, Brasov, Romania, 1: 182-185.

Franc, S., Peulić, V. (2017) Examining Slovenian trade flow sustainability: empirical evidence from the 
Skoko, B., Zovko, P.

Sustainability of Bosnia and Herzegovina's international trade flows period of the EU membership. Notitia - časopis za održivi razvoj, 3: 25-32.

Gnimassoun, B., Coulibaly, I. (2014) Current account sustainability in Sub-Saharan Africa: Does the exchange rate regime matter? Economic Modelling, 40: 208-226.

Greenidge, K., Holder, C., Moore, A. (2011) Current account deficit sustainability: the case of Barbados. Applied Economics, 43 (8): 973-984.

Holmes, M.J., Panagiotidis, T., Sharma,A. (2011) The sustainability of India's current account. Applied Economics, 43 (2): 219-229.

Husted S. (1992) The Emerging US Current Account Deficit In The 1980s: A Cointegration Analysis. The Review of Economic and Statistics, 74: 159-166.

Hye, Q. M. A., Siddiqui, M. M. (2010) Are Imports and Exports Cointegrated in Pakistan? A Rolling Window Bound Testing Approach. World Applied Sciences Journal, 9 (7):708-711.

Insel, A., Kayikci, F. (2012) Evaluation of sustainability of current account deficits in Turkey. Modern Economy, 3 (1): 43.

Johansen, S. (1988) Statistical Analysis of Cointegration Vectors. Journal of Economic Dynamics and Control, 12 (2): 231-254.

Johansen, S. (1991) Estimation and Hypothesis Testing of Cointegration Vectors in Gaussian Vector Autoregressive Models. Econometrica, 59 (6): 1551-1580.

Johansen, S. (1995) Likelihood-Based Inference in Co-integrated Vector Autoregressive Models. Oxford: Oxford University Press.

Johansen, S., Juselius, K. (1990) Maximum Likelihood Estimation and the Demand for Money Inference on Cointegration with Application. Oxford Bulletin of Economics and Statistics, 52: 169-210.

Kalyoncu, H., Ozturk, I. (2010) Sustainability of current account for Latin America and Caribbean countries. Applied Economics Letters, 17 (8): 781-785.

Kling, J. L., Bessler, D. A. (1985) A comparison of multivariate forecasting procedures for economic time series. International Journal of Forecasting, 1: 5-24.

Polat, 0̈. (2011) Sustainability of the current account deficit in Turkey. African Journal of Business Management, 5 (2): 577-581.

Shastri, S., Giri, A. K., Mohapatra, G. (2018) An empirical assessment of current accounts sustainability for major South Asian economies. South Asian Journal of Business Studies, 7 (2): 172-188.

Sims, C.A. (1982) Policy analysis with econometric models. Brookings Papers on Economic Activity, 1982: $107-164$ 